\title{
Program Kemitraan Masyarakat Stimulus Rumah Jahit Nia
}

\author{
Siti Rodiah*, Wira Ramashar, Zul Azmi \\ Fakultas Ekonomi dan Bisnis, Universitas Muhammadiyah Riau \\ email: sitirodiah@umri.ac.id
}

\begin{abstract}
Community service aims to provide understanding to the Nia Sewing House in separating financial records between owners and businesses as well as training in preparing the cost of production. This activity was carried out at the Nia Sewing House Jl. Merak Gg. Merak 1 Kec. Bukit Raya Kel. Tangkerang Labuai. This activity was made after conducting an initial survey that found that the Nia Sewing House had not applied the concept of business entities in its business so that the recording of the two was mixed, besides that the Nia Sewing House also had not compiled financial statements. After this activity is done Nia's Sewing House is expected to be able to compile its own financial statements and find out how much profit it has.
\end{abstract}

Keywords: Business Entity Concept, Cost of Production

\begin{abstract}
Abstrak
Pelatihan dan penyuluhan ini dimaksudkan untuk memberikan pemahaman tentang penghitungan biaya pokok produksi. Kegiatan ini dilakukan di lokasi tempat tinggal sekaligus tempat usaha mitra "Rumah Jahit Nia" yang terletak di Jalan Merak Gg. Merak I Kelurahan Tangkerang Labuai Kecamatan Bukit Raya Kota Pekanbaru. Berdasarkan hasil kunjungan dan wawancara ke lokasi mitra diperoleh informasi bahwa mitra tidak dapat menghitung harga pokok produksi jahit pakaian serta tidak dapat mengetahui seberapa besar laba atau rugi usaha yang diperoleh dalam satu periode. Pelatihan dan penyuluhan diikuti langsung oleh pemilik sekaligus pengelola usaha beserta suaminya. Hasilnya menunjukkan bahwa mitra mendapatkan pemahaman dan pengetahuan dalam menghitung harga pokok produksi jahit pakaian serta menghitung laba rugi yang diperoleh. Dengan adanya kegiatan ini mitra merasa sangat terbantu dan diharapkan pada akhirnya dapat menyusun laporan keuangan dengan baik.
\end{abstract}

Kata Kunci: Biaya Pokok Produksi, Laba Rugi, Laporan Keuangan

\section{PENDAHULUAN}

Salah satu jenis Usaha Mikro, Kecil dan Menengah (UMKM) yang cukup berkembang adalah usaha jahit pakaian. Usaha ini sangat menjanjikan terutama bagi yang hobi dan memiliki keahlian serta keterampilan menjahit. Usaha ini tidak terlalu mengalami pasang surut, karena hampir setiap tahun, tukang jahit pakaian mendapatkan orderan untuk menjahit berbagai macam model pakaian. Terlebih pada momen-momen tertentu orderan semakin meningkat seperti saat menyambut lebaran, anak masuk sekolah dan lain sebagainya. Semakin lama kebutuhan akan pakaian sangat tinggi seiring dengan perkembangan fashion yang selalu mengalami perubahan.

"Rumah Jahit Nia" adalah salah satu usaha jahit pakaian yang menjadi perhatian. Usaha ini didirikan pada tahun 2009 dan saat ini sudah semakin berkembang. Hal ini terlihat dari banyaknya jumlah pelanggannya. Rumah jahit Nia ini dapat menjahit berbagai jenis pakaian seperti kemeja, gamis, baju melayu, jas, gaun, baju 
pengantin dan lainnya. Pangsa pasarnya saat ini juga sudah merambah ke pejabatpejabat pemerintah daerah dan kalangan ekonomi atas.

Dalam menjalankan usahanya, Nia selaku pemilik dan pengelola dibantu oleh 13 (tiga belas) orang karyawan yang memiliki kahlian dan job desk masingmasing seperti tukang potong, tukang jahit, tukang obras, tukang bordir dan finishing. Teknik pemasaran yang dilakukan yaitu informasi dari mulut ke mulut dan juga melalui media masa seperti facebook dan instagram. Namun demikian masih terdapat kelemahan atau permasalahan yang dialami oleh mitra yaitu tidak dapat mengetahui seberapa besar laba atau rugi yang diperoleh setiap bulannya. Selain itu mitra juga tidak dapat menghitung harga pokok produksi satu lembar pakaian. Hal ini dikarenakan kurangnya pemahaman dan pengetahuan tentang pencatatan dan penyusunan laporan keuangan yang baik

Berdasarkan permasalahan tersebut dosen prodi Akuntansi Fakultas Ekonomi dan Bisnis Universitas Muhammadiyah Riau berminat untuk melakukan pengabdian masyarakat dengan memberikan pelatihan tentang menghitung besarnya harga pokok produksi dan pembuatan laporan keuangan terutama laporan laba rugi usaha.

\section{Konsep Entitas Bisnis (Business Entity Concept) dan Usaha Mikro Kecil dan Menengah (UMKM)}

Konsep entitas binis adalah asumsi dasar akuntansi keuangan karena konsep ini membatasi data ekonomi dalam system akuntansi ke data yang berhubungan langsung dengan aktivitas usaha. Dengan kata lain, bisnis dipandang sebagai entitas terpisah dari pemilik, kreditor, atau pihak pemangku kepentingan lainnya (Warren, C.S, Reeve, J.M, Duchac, J.E, Wahyuni, E.T, Jusuf, 2017).
Berdasarkan konsep entitas bisnis tersebut, usaha mikro, kecil dan menengah (UMKM) dipandang sebagai satu kesatuan entitas yang terpisah dari pemilik. Hal ini sesuai dengan Undangundang Nomor 20 Tahun 2008 tentang (UMKM):

a. Usaha mikro adalah usaha produktif milik orang perorangan dan/atau badan usaha perorangan yang memenuhi kriteria usaha mikro sebagaimana diatur dalam undangundang ini.

b. Usaha kecil adalah usaha produktif yang berdiri sendiri, yang dilakukan oleh orang perorangan atau badan usaha yang bukan merupakan anak perusahaan atau bukan cabang perusahaan yang dimiliki, dikuasai, atau menjadi bagian baik langsung maupun tidak langsung dari usaha menengah atau usaha besar yang memenuhi kriteria usaha kecil sebagaimana dimaksud dalam Undang-undang ini.

c. Usaha menengah adalah usaha ekonomi produktif yang berdiri sendiri, yang dilakukan oleh orang perorangan atau badan usaha yang bukan merupakan anak perusahaan atau cabang perusahaan yang dimiliki, dikuasai, atau menjadi bagian baik langsung maupun tidak langsung dengan usaha kecil atau usaha besar dengan jumlah kekayaan bersih atau hasil penjualan tahunan sebagaimana diatur dalam UndangUndang ini.

d. Kriteria UMKM berdasarkan jumlah asset dan omzet.

Tabel 1. Kriteria UMKM berdasarkan jumlah asset dan omzet.

\begin{tabular}{|c|c|c|}
\hline Jenis Usaha & Asset & Omzet \\
\hline Usaha Mikro & $\begin{array}{l}\text { Max } 50 \\
\text { Juta }\end{array}$ & $\begin{array}{l}\text { Maksimal } \\
\text { 300 Juta }\end{array}$ \\
\hline $\begin{array}{l}\text { Usaha Kecil } \\
\text { Besar }\end{array}$ & $\begin{array}{l}\text { dari } 50 \\
\text { jt-500 jt }\end{array}$ & $\begin{array}{l}\text { dari } 50 \\
\text { Juta-500 } \\
\text { Juta }\end{array}$ \\
\hline
\end{tabular}




\begin{tabular}{|l|l|l|}
\hline Jenis Usaha & \multicolumn{1}{|c|}{ Asset } & \multicolumn{1}{|c|}{ Omzet } \\
\hline Usaha & dari 500 & Besar dari \\
Menengah & Juta-10 & $2,5 \mathrm{M}-50$ \\
Besar & $\mathrm{M}$ & $\mathrm{M}$ \\
\hline
\end{tabular}

\section{Laporan Keuangan UMKM Berdasarkan SAK EMKM}

Dewan Standar Akuntansi Keuangan (DSAK) IAI dalam pengesahan Standar Akuntansi Keuangan Entitas Mikro, Kecil, dan Menengah (ED SAK EMKM) pada tanggal 18 Mei 2016 yang selanjutnya disebut SAK EMKM dan berlaku efektif pada 1 Januari 2018 menyatakan bahwa laporan keuangan UMKM terbagi menjadi tiga yaitu:

1. Laporan posisi keuangan pada akhir periode,

2. Laporan laba rugi selama periode,

3. Catatan atas laporan keuangan.

\section{A. Laporan Laba Rugi}

Laporan laba rugi adalah laporan yang menunjukkan kemampuan perusahaan atau entitas bisnis menghasilkan keuntungan pada suatu periode waktu tertentu, misalnya satu bulan atau satu tahun. Laporan laba rugi enitas dapat mencakup akun-akun sebagai berikut (Rudianto, 2012):

1. Pendapatan

Pendapatan adalah kenaikkan kekayaan perusahaan akibat penjualan produk perusahaan dalam rangka kegiatan usaha normal.

2. Beban usaha

Beban usaha adalah pengorbanan ekonomis yang dilakukan perusahaan untuk memperoleh barang dan jasa yang akan digunakan dalam usaha normal dan bermanfaat selama suatu periode tertentu. Beban usaha terdiri dari berbagai beban yang berbeda antara yang satu dengan yang lainnya, seperti beban gaji, beban transportasi, beban listrik serta telepon, dan sebagainya.

\section{B. Catatan Atas Laporan Keuangan}

Catatan atas laporan keuangan mencakup sebagai berikut :

1. Suatu pernyataan bahwa laporan keuangan telah disusun sesuai dengan SAK EMKM

2. Ikhtisar kebijakan akuntansi

3. Informasi tambahan dan rincian akun tertentu yang menjelaskan transaksi penting dan material sehingga bermanfaat bagi pengguna untuk memahami laporan keuangan.

\section{Biaya Pokok Produksi}

Biaya produksi adalah biaya yang terjadi dalam fungsi produksi yaitu yang mengolah bahan baku menjadi barang jadi. Biaya produksi terdiri dari 3 komponen yaitu (Riwayadi, 2019).

1. Biaya bahan baku

Biaya bahan baku terbagi menjadi dua yaitu:

a) Bahan baku langsung adalah bahan yang dapat secara mudah dan akurat ditelusuri sampai ke barang jadi. Contohnya adalah kain untuk pembuatan baju.

b) Bahan baku tidak langsung adalah bahan baku yang tidak secara mudah dan akurat ditelusuri ke produk. Contohnya adalah bahan penolong seperti benang untuk pembuatan baju.

2. Biaya tenaga kerja langsung

Tenaga kerja langsung adalah tenaga kerja yang terlibat langsung dalam pembuatan barang jadi dan pembayaran upahnya berdasarkan unit yang dihasilkan atau berdasarkan jam kerja, misalnya upah Rp 50.000 per unit atau $\mathrm{Rp} 5.000$ per jam. Sedangkan biaya tenaga kerja langsung adalah upah yang dibayarkan kepada tenaga kerja langsung.

3. Biaya overhead pabrik 
Biaya overhead pabrik adalah semua biaya produksi selain biaya bahan baku langsung dan biaya tenaga kerja langsung yang tidak dapat secara mudah dan akurat ditelusuri ke produk. Contohnya adalah beban penyusutan mesin jahit.

\section{Tujuan Kegiatan dan rencana pemecahan masalah}

Dari hasil kunjungan ke lapangan dan informasi yang diperoleh dari mitra serta penjelasan di atas dapat diringkas permasalah mitra yang terjadi adalah sebagai berikut:

1. Kurangnya pengetahuan tentang penghitungan harga pokok produksi jahit pakaian.

2. Tidak dapat menentukan berapa jumlah laba yang diperoleh setiap bulannya atau periode.

Adapun tujuan dari pelaksanaan kegiatan pengabdian ini adalah untuk:

1. Memberikan pengetahuan tentang bagaimana cara menghitung harga pokok produksi satu lembar pakaian.

2. Memberikan pengetahuan tentang menghitung seberapa besar laba atau keuntungan usaha yang diperoleh, dan;

3. Memberikan pelatihan dan pengetahuan tentang membuat laporan keuangan.

Dalam rangka membantu memecahkan permasalahan yang dihadapi oleh mitra maka ditawarkan solusi melalui program pelatihan dalam menentukan harga pokok produksi dan menyusun laporan keuangan.

\section{METODE PENGABDIAN Materi dan Pelaksana}

Pelaksanaan kegiatan pengabdian kegiatan masyarakat ini diawali dengan kunjungan lapangan untuk melakukan analisa situasi, dan melakukan wawancara kepada pemilik atau pengelola usaha UMKM jahit pakaian selaku mitra Langkah selanjutnya yaitu mempersiapkan bahan-bahan dan peralatan yang diperlukan dalam kegiatan pengabdian. Dan langkah terakhir yaitu melakukan kegiatan pelatihan dan workshop yang diberikan kepada mitra agar dapat memecahkan masalah yang dihadapi. Dari hasil observasi lapangan dan diskusi dengan mitra terkait permasalahan yang dihadapi, maka materi yang diberikan antara lain: (a) memberikan edukasi tentang literasi keuangan bahwa pentingnya memisahkan keuangan pribadi atau keluarga dengan keuangan usaha; (b) memberikan pengetahuan tentang cara menghitung harga pokok produksi satu lembar pakaian; dan (3) memberikan pengetahuan dalam menyusun laporan keuangan dari usaha yang dijalankan sehingga nantinya mitra dapat mengetahui seberapa besar laba atau rugi yang diperoleh.

Kegiatan pengabdian masyarakat ini dilakukan oleh 3 (tiga) orang dosen Program Studi Akuntansi Fakultas Ekonomi dan Bisnis Universitas Muhammadiyah Riau. Dalam pelaksaannya tim dosen juga dibantu oleh beberapa orang mahasiswa. Sedangkan mitra berperan dalam memfasilitasi lokasi pelatihan dan informasi yang cukup serta menyediakan data-data yang mendukung terkait dengan permasalahan riil yang terjadi.

\section{Tempat dan Waktu}

Pelaksanaan kegiatan pengabdian masyarakat ini dilakukan di rumah tempat tinggal sekaligus tempat usaha mitra yang berlokasi Jl. Merak Gg. Merak I Kel. Tangkerang Labuai Kec. Bukit Raya Kota Pekanbaru pada hari Sabtu tanggal 07 Desember 2019.

\section{Ruang Lingkup dan Objek Pengabdian \\ Pada kegiatan ini yang menjadi mitra adalah pelaku UMKM yaitu}


pemilik usaha jahit pakaian dengan merk usaha "RUMAH JAHIT NIA" yang berlokasi Jl. Merak Gg. Merak I Kel. Tangkerang Labuai Kec. Bukit Raya Kota Pekanbaru.

\section{HASIL DAN PEMBAHASAN}

Aktivitas pengabdian masyarakat ini dimulai dengan melakukan ksurvey atau kunjungan lapangan ke lokasi usaha yang menjadi mitra dalam pelaksanaan kegiatan pengabdian. Kemudian dilakukan analisa situasi dan wawancara serta rapat koordinasi dengan mitra. Hal ini dilakukan untuk mengetahui permasalahan yang dihadapi mitra dan untuk menentukan solusi apa yang dapat diberikan.

Pada tahap selanjutnya adalah pelaksanaan kegiatan pengabdian. Pada tahap ini pemateri memberikan edukasi tentang literasi keuangan mengenai pentingnya pemisahan keuangan pribadi atau keluarga dengan keuangan usaha. Edukasi ini diberikan agar mempermudah dalam pembuatan laporan keuangan. Kemudian mitra diberikan pengetahuan dan pelatihan tentang cara menghitung harga pokok produksi satu lembar pakaian. Dan materi terakhir yang diberikan adalah pelatihan membuat laporan keuangan. Dengan adanya pelatihan ini diharapkan mitra dapat menghitung dan mengetahui seberapa besar laba atau rugi yang diperoleh dari hasil usaha yang dijalankan dalam satu periode.

Workshop dan pelatihan kepada mitra diberikan selama lebih kurang 3 jam dan kemudian dilanjutkan dengan diskusi antara peserta dengan pemateri. Pada sesi diskusi, para peserta terlihat sangat antusias dengan menyampaikan pertanyaan-pertanyaan terkait dengan permasahan yang selama ini mereka hadapi di praktiknya. Pada akhir kegiatan, pemateri dan mitra berfoto bersama sebagai bentuk dokumentasi pelaksanaan kegiatan pengabdian.

\section{SIMPULAN}

Dari kegiatan pengabdian masyarakat dapat diambil kesimpulan sebagai berikut:

1. Mitra dapat mengetahui pentingnya pemisahan keuangan pribadi/keluarga dengan keuangan usaha;

2. Mitra dapat pengetahuan tentang cara menghitung harga pokok produksi jahit pakaian;

3. Mitra dapat menyusun laporan keuangan dengan baik sehingga dapat mengetahui seberapa besar laba/rugi yang diperoleh setiap periodenya.

Dengan adanya kegiatan ini diharapkan dapat berlanjut. Pengabdian selanjutnya tetap diarahkan pada sharing masalah yang dihadapi oleh mitra dan pengembangan pengelolaan keuangan serta pendampingan baik dari segi aspek manajemen, pemasaran dan keuangan.. Pengabdian selanjutnya agar memperluas tempat kegiatan pengabdian disarankan.

\section{DAFTAR PUSTAKA}

[1] Ikatan Akuntan Indonesia. (2016). Standar Akuntansi Keuangan Entitas Mikro, Kecil, dan Menengah. Jakarta

[2] Riwayadi. (2019). Akuntansi Biaya Pendekatan Tradisional dan Kontemporer. (Ed. 2). Jakarta: Salemba Empat.

[3] Rudianto. (2012). Pengantar Akuntansi Konsep dan Tehknik Penyusunan Laporan Keuangan. Jakarta: Erlangga.

[4] Warren, C.S, Reeve, J.M, Duchac, J.E, Wahyuni, E.T, Jusuf, A. A. (2017). Pengantar Akuntansi 1 Adapatasi Indonesia. (4th ed.). Jakarta: Salemba Empat. 